\title{
COVID-19 in heart transplant recipients
}

\section{CPetra Mjehović* , - Maja Čikeš, (1) Mia Dubravčić, ○Dora Fabijanović, (C)Nina Jakuš, (D)Hrvoje Jurin, DDaniel Lovrić, (1) Jana Ljubas Maček, - Marijan Pašalić, Olvo Planinc, (1) Jure Samardžić, (1)Boško Skorić, (1)Davor Miličić}

University of Zagreb School of Medicine, University Hospital Centre Zagreb, Zagreb, Croatia
RECEIVED:

December 6, 2020

ACCEPTED:

December 18, 2020

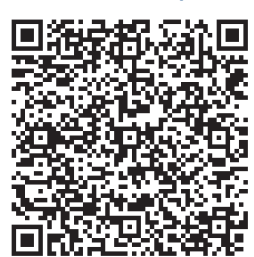

KEYWORDS: heart transplantation, COVID-19, immunosuppression therapy. CITATION: Cardiol Croat. 2021;16(1-2):25-6. | https://doi.org/10.15836/ccar2021.25

*ADDRESS FOR CORRESPONDENCE: Petra Mjehović, Klinički bolnički centar Zagreb, Kišpatićeva 12, HR-10000 Zagreb, Croatia. / Phone: +385-91-8970556 / E-mail: petra.mjehovic@gmail.com

ORCID: Petra Mjehović, https://orcid.org/0000-0003-4908-4674 • Maja Čikeš, https://orcid.org/0000-0002-4772-5549 Mia Dubravčić, https://orcid.org/0000-0003-0441-4772 • Dora Fabijanović, https://orcid.org/0000-0003-2633-3439 Nina Jakuš, https://orcid.org/0000-0001-7304-1127 • Hrvoje Jurin, https://orcid.org/0000-0002-2599-553X Daniel Lovrić, https://orcid.org/0000-0002-5052-6559 • Jana Ljubas Maček, https://orcid.org/0000-0001-7171-2206 Marijan Pašalić, https://orcid.org/0000-0002-3197-2190 • Ivo Planinc, https://orcid.org/0000-0003-0561-6704 Jure Samardžić, https://orcid.org/0000-0002-9346-6402 • Boško Skorić, https://orcid.org/0000-0001-5979-2346 Davor Miličić, https://orcid.org/0000-0001-9101-1570

IIIIIIIIIIIIIIIIIIIIIIIIIIIIIIIIIIIIIIIIIIIIIIIIIIIIIIIIIIIIIIIIIIIIIIIIIIIIIIIIIIIIIIIIIIIIIIIIIIIIIIIIIIIIIIIIIIIIII

Introduction: Data on heart transplant (HTx) patients and infection with acute respiratory syndrome coronavirus 2 (SARS-CoV-2) are very limited. There is significant heterogeneity in the clinical presentation. ${ }^{1}$ Immunosuppression-related issues are of the main concern because of an increased risk for viral replication and superimposed infections. There is no evidence-based recommendation for the management of these patients. Some authors suggest modification in immunosuppression, i.e. discontinuation of mycophenolate mofetil (MMF) and calcineurin inhibitor (CNI) reduction in patients with more severe clinical presentation. ${ }^{2}$

Patients and Methods: This is a case series of $5 \mathrm{HTx}$ recipients from our center who tested positive for COVID-19 infection and were treated in different COVID-19 specialized units.

Results: There were 4 male and one female patients, 62-75 years old. Four of them were symptomatic and hospitalized, while one remained self-quarantined at home. The clinical presentation was mild to moderate, with symptoms including mild fever, dyspnea, and myalgia. X-ray signs of pneumonia were present in 3 patients, but none needed ICU care nor mechanical ventilation. Both a reduction of CNI dose with lower target serum concentration and MMF was discontinued in all patients. One patient was treated with hydroxychloroquine, one with remdesivir and one with steroid therapy. Antibiotics prophylaxis was administered in 2 patients. None of the patients experienced overt graft rejection and all patients have successfully recovered (Table 1).

Conclusion: Lacking any evidence-based recommendation for the treatment of HTx patients infected with SARS-CoV-2, we are challenged to modify maintenance immunosuppression carefully balancing between the risk of uncontrolled viral replication with a superimposed infection on one side, and the increased risk of graft rejection on the other side. Further studies are needed to determine the optimal management of COVID-19 infection in these patients. 
TABLE 1. Main characteristics of the 5 heart transplant patients with COVID-19.

\begin{tabular}{|c|c|c|c|c|c|}
\hline & Patient 1 & Patient 2 & Patient 3 & Patient 4 & Patient 5 \\
\hline Age (years) & 63 & 57 & 62 & 75 & 66 \\
\hline Gender & Female & Male & Male & Male & Male \\
\hline Time from HTx (years) & 3 & 3 & 3 & 10 & 5 \\
\hline \multicolumn{6}{|c|}{ Imumunosuppressive therapy (mg/day) } \\
\hline Tacrolimus & 1.5 & 2 & - & 1.5 & - \\
\hline Cyclosporine & - & - & 160 & - & 160 \\
\hline Mycophenolate mofetil & 1500 & - & 3000 & 2000 & 2000 \\
\hline Everolimus & - & 0.5 & - & - & - \\
\hline \multicolumn{6}{|l|}{ COVID-19 onset } \\
\hline \multicolumn{6}{|l|}{ Presenting symptoms } \\
\hline Cough & - & + & - & - & - \\
\hline Shortness of breath & + & + & + & - & + \\
\hline Myalgia & + & + & + & - & + \\
\hline Anosmia & + & + & - & - & - \\
\hline Headache & + & - & - & - & + \\
\hline Sinusitis & - & - & - & - & - \\
\hline Gastrointestinal symptoms & - & - & - & - & + \\
\hline NPS test & + & + & + & + & + \\
\hline X-ray pneumonia signs & - & + & + & - & + \\
\hline Fever peak $\left({ }^{\circ} \mathrm{C}\right)$ & 37.9 & 38 & 37.6 & 36.6 & 37.8 \\
\hline Hospitalization & - & + & + & + & + \\
\hline $\mathrm{SpO}_{2}$ at admission (\%) & 1 & 90 & 95 & 96 & 96 \\
\hline Worst $\mathrm{SpO}_{2}$ during hospitalization & 1 & 90 & 94 & 91 & 96 \\
\hline \multicolumn{6}{|l|}{ Laboratory results at admission } \\
\hline WBC count (cells per $10^{9} / \mathrm{l}$ ) & 4.0 & 5.5 & 5.3 & 2.8 & 7.5 \\
\hline $\mathrm{Hb}(\mathrm{g} / \mathrm{l})$ & 121 & 139 & 139 & 105 & 149 \\
\hline Platelets (cells per $10^{9} /$ ) & 283 & 124 & 192 & 111 & 140 \\
\hline Lymphoyte (cells per $10^{9} / \mathrm{l}$ ) & 0.60 & 1.70 & 0.55 & 0.62 & 1 \\
\hline CRP (mg/l) & 0.9 & 57.4 & 6.8 & 0.4 & 20 \\
\hline Creatinine (umol/l) & 107 & 126 & 72 & 136 & 169 \\
\hline Troponin I (ug/l) & 1 & 1 & 4 & 1 & 1 \\
\hline \multicolumn{6}{|l|}{ Treatment and outcomes } \\
\hline Hydroxychloroquine & - & - & - & - & + \\
\hline Remdesivir & - & - & + & - & - \\
\hline Corticosteroid therapy & - & + & - & - & - \\
\hline $\begin{array}{l}\text { Discontinuation of mycophenolate } \\
\text { mofetil }\end{array}$ & + & + & + & + & + \\
\hline Antibiotics prophylaxis & - & + & - & - & + \\
\hline ICU stay & - & - & - & - & - \\
\hline Mechanical ventilation & - & - & - & - & - \\
\hline Complications & - & - & - & - & - \\
\hline In-hospital length of stay (days) & 1 & 5 & 9 & 21 & 11 \\
\hline Outcome & Alive & Alive & Alive & Alive & Alive \\
\hline
\end{tabular}

NPS- nasop haryngeal swab test, $\mathrm{SpO}_{2}$ - oxygen saturation, $\mathrm{CRP}$ - C-reactive protein, ICU - intensive care unit

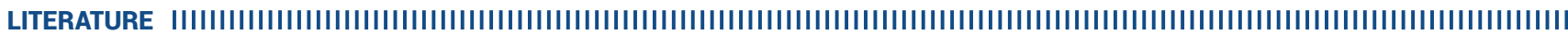

1. Caraffa R, Bagozzi L, Fiocco A, Bifulco O, Nadali M, Ponzoni M, et al. Coronavirus disease 2019 (COVID-19) in the heart transplant population: a single-centre experience. Eur J Cardiothorac Surg. 2020 Nov 1;58(5):899-906. https://doi.org/10.1093/ejcts/ezaa323

2. Latif F, Farr MA, Clerkin KJ, Habal MV, Takeda K, Naka Y, et al. Characteristics and Outcomes of Recipients of Heart Transplant With Coronavirus Disease 2019. JAMA Cardiol. 2020 May 13:e202159. https://doi.org/10.1001/jamacardio.2020.2159 